\title{
PIOTR ROBAKOWSKI
}

Uniwersytet Gdański ORCID: 0000-0003-1641-2643

piotr.robakowski@ug.edu.pl

JOANNA SYNOWEĆ

Politechnika Gdańska

ORCID: 0000-0002-8585-1458

joanna.synowec@gmail.com

\section{POLITYKA ZDROWOTNA RP - CO ZMIENIEO SIE W DOBIE COVID-19?}

\section{Health Policy in the Republic of Poland: What Has Changed During the COVID-19 Pandemic}

The SARS-CoV-2 pandemic has shocked the entire world. Countries and regions have had to learn to live in the new reality. It has been an enormous challenge for governments that have had to learn to provide livelihoods in times of economic crisis. Health policy plays a special role in this process as it is responsible for the health and life of citizens.

The aim of this article is to describe Polish health policy and the changes that have taken place in it during the COVID-19 pandemic. The work was created during the pandemic, in the period when the next wave of infections was expected in the autumn-winter season. For this reason, the data and conclusions concern the epidemiological crisis.

Keywords: health policy during COVID-19, health protection during COVID-19, COVID-19, coronavirus pandemic, health policy.

\section{WSTEP}

W światowej świadomości rok 2020 został zdominowany przez pandemię choroby COVID-19. Zawrotna szybkość rozprzestrzeniania się wirusa SARS-CoV-2 wpłynęła na praktycznie każdy aspekt funkcjonowania krajów i społeczeństw. W większości państw pandemia wywołała 
stan zagrożenia kryzysowego. COVID-19, ze względu na swój gwałtowny charakter, jest szczególnym wyzwaniem dla systemów ochrony zdrowia. Celem niniejszego artykułu jest zaprezentowanie aktualnej sytuacji polskiej opieki medycznej (stan na 6 września 2020 r.). Przesłanka artykułu jest stwierdzenie, że system ochrony zdrowia pomimo istniejących wcześniej problemów musiał zmierzyć się z kolejnymi, które dotyczyły już całego świata. Aby wyraźniej przedstawić położenie Polski, w końcowej części tekstu krótko scharakteryzowano sytuację panujaca w brytyjskim systemie ochrony zdrowia oraz jego metody radzenia sobie $z$ kryzysem.

\section{POLITYKA ZDROWOTNA RP}

Aktualne założenia polskiej polityki zdrowotnej zostały przedstawione w Narodowym Programie Zdrowia (NPZ) na lata 2016-2020. Jest to dokument zawierający zapis spójnej polityki zdrowotnej, którą realizuja organy państwowe. Program przyjęto w drodze Rozporządzenie Rady Ministrów z dnia 4 sierpnia 2016 r. w sprawie Narodowego Programu Zdrowia na lata 2016-2020 (Dz.U. 2016, poz. 1492). Jest to piata wersja programu. Pierwsza strategie opracowano na początku lat 90. XX wieku jako odpowiedź na dokument Światowej Organizacji Zdrowia „Zdrowie dla wszystkich w roku 2000”. Akt był pionierska próba zjednoczenia różnych organów administracji rządowej, społeczności lokalnych i organizacji pozarządowych w celu poprawy, utrzymania i ochrony zdrowia Polaków. Intensywne zmiany społeczne, polityczne i ekonomiczne lat 90. w Polsce niosły poza różnymi możliwościami zagrożenie zdrowia wielu grupom funkcjonujaccym w społeczeństwie. $Z$ tego względu Narodowy Program Zdrowia był aktualizowany w 1993 i 1996 r. Kolejne strategie powstawały w 2002 i 2006 r. Ich celem była efektywna absorpcja środków wspólnotowych oraz harmonijny rozwój regionalny. W 2005 r. w drodze uchwały przyjęto „Strategię rozwoju ochrony zdrowia w Polsce na lata 2007-2013", której głównym elementem był Narodowy Program Zdrowia przygotowany na lata 2007-2015 .

Celem strategicznym NPZ na lata 2016-2020 jest zmniejszenie nierówności społecznych w zakresie zdrowia, poprawę jakości życia ludności poprzez zwiększenie zdrowotności i wydłużenie życia w zdrowiu. Cele operacyjne wraz z podmiotami odpowiedzialnymi i przykładami działań prezentuje tabela 1. Narodowy Program Zdrowia jest

1 NPZ 2007-2015, Ministerstwo Zdrowia, http://www.archiwum.mz.gov.pl/zdrowie-iprofilaktyka/narodowy-program-zdrowia/npz-2007-2015/ [dostęp: 1 września 2020]. 


\begin{tabular}{|c|c|c|c|c|c|}
\hline 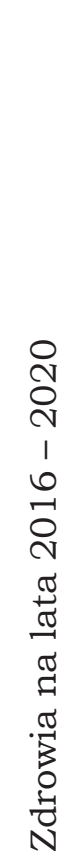 & 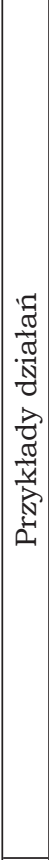 & 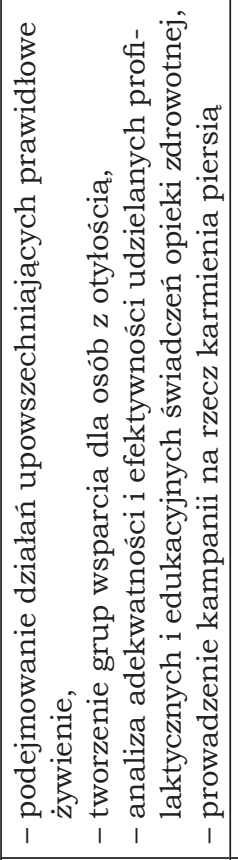 & 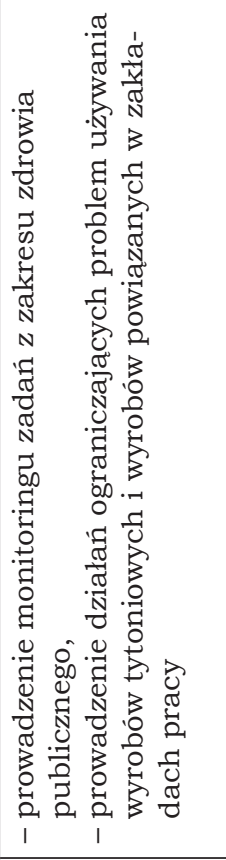 & 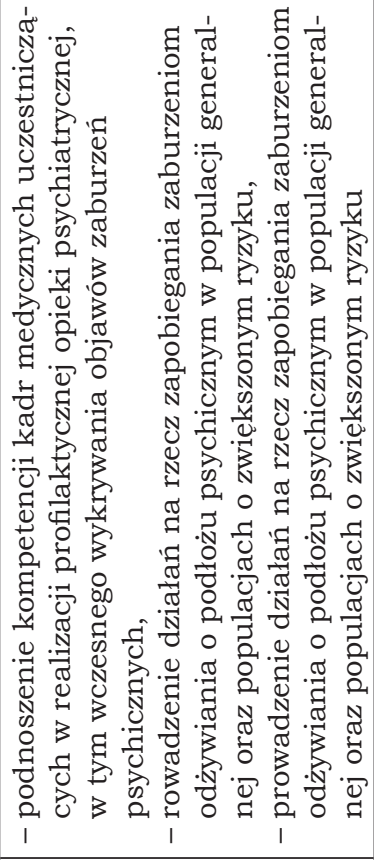 & 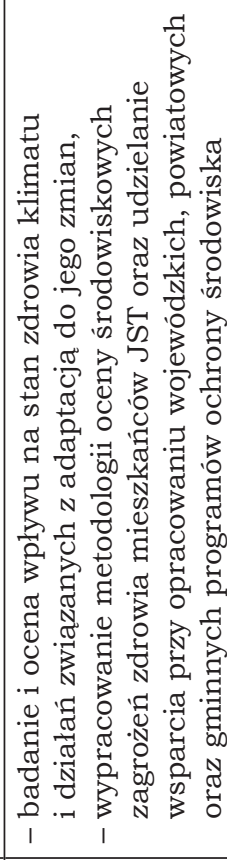 \\
\hline 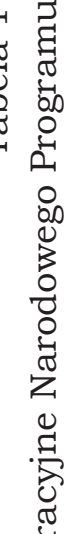 & 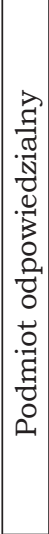 & 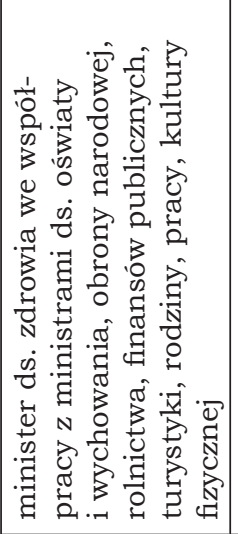 & 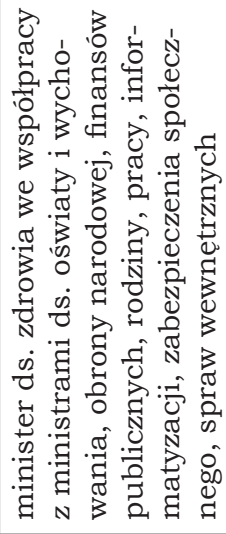 & 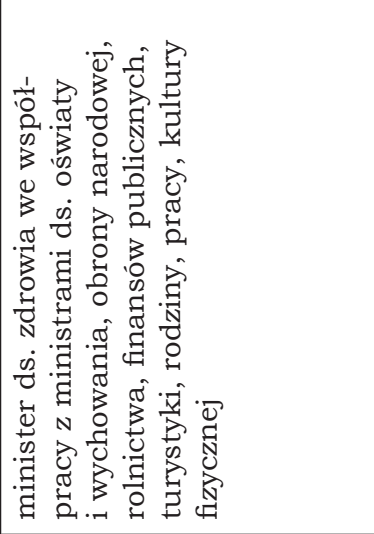 & 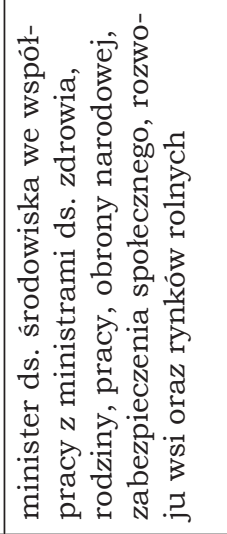 \\
\hline $\begin{array}{l}0 \\
0 \\
0 \\
\frac{0}{0} \\
U\end{array}$ & 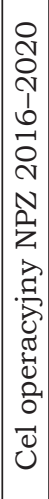 & 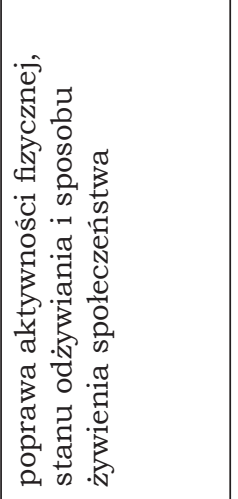 & 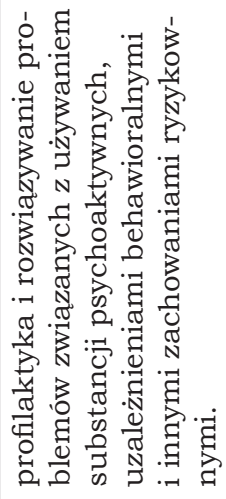 & 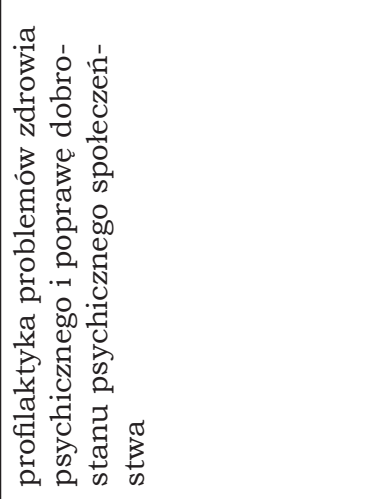 & 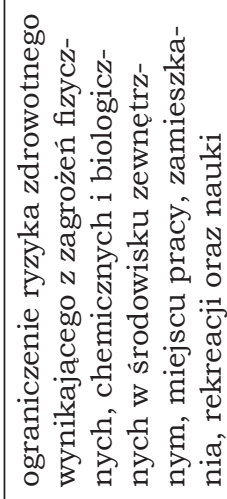 \\
\hline
\end{tabular}




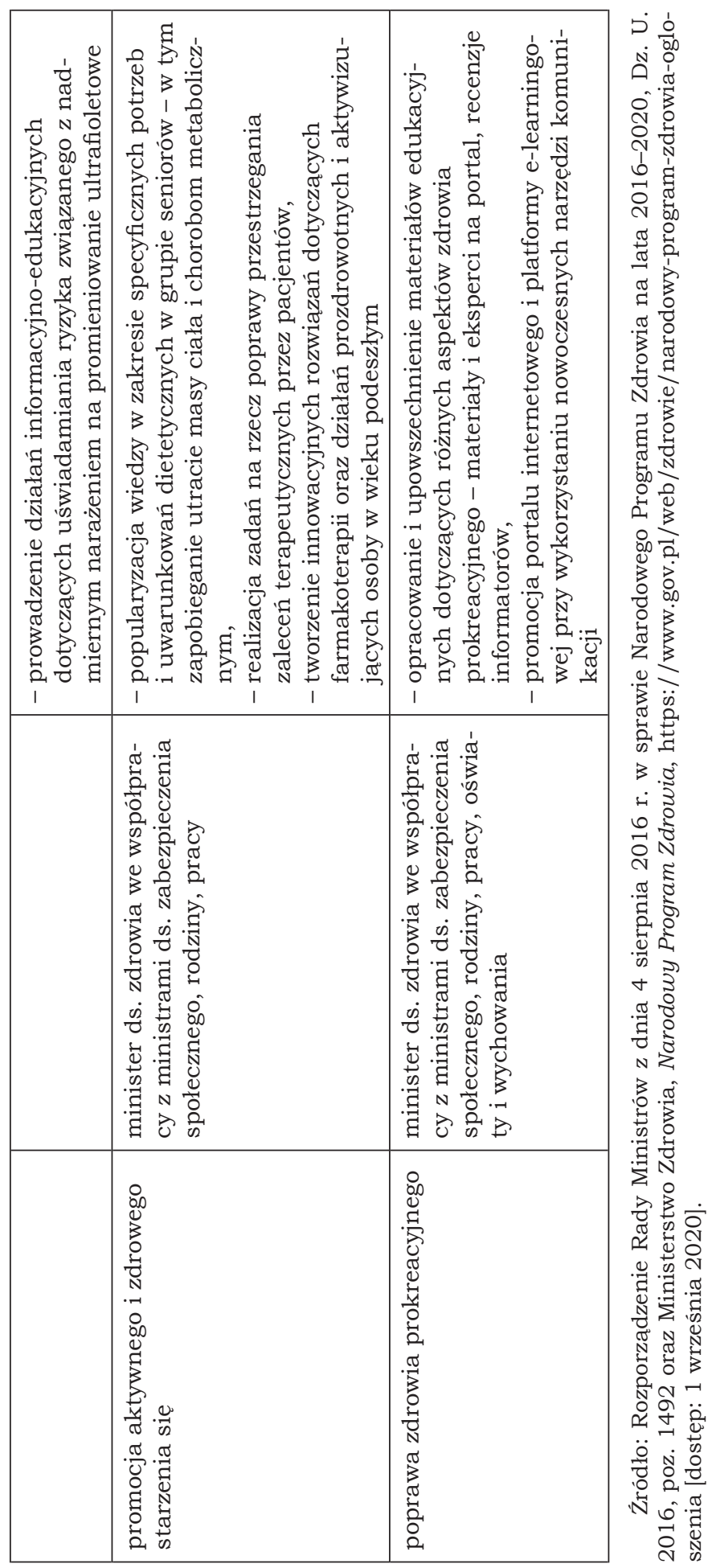


systematycznie monitorowany i sprawozdawany zgodnie $z$ „Programem monitorowania oczekiwanych efektów i korzyści zdrowotnych wynikajaccych z realizacji NPZ" z 1998 roku. Opisano w nim metodykę ewaluacji polityki zdrowotnej kraju².

W 2015 r. przyjęto kolejny dokument decydujący o sposobie prowadzenia polityki zdrowotnej w Polsce - ustawę $z$ dnia 11 września 2015 r. o zdrowiu publicznym (Dz.U. 2015, poz. 1916 z późn. zm.). Akt prawny określa zadania $z$ zakresu zdrowia publicznego, podmioty je realizujacce oraz zasady ich finansowania. Dokument był odpowiedzią na potrzebe poprawy stanu zdrowia ludności. W tym celu utworzono też nowe ciała koordynacyjne i doradcze, czyli Radę ds. Zdrowia Publicznego oraz Komitet Sterujacy Narodowym Programem Zdrowia.

Przyjmuje się, że w 2017 roku poniesiono ponad 130 mld PLN wydatków bieżących na ochronę zdrowia, co stanowiło 6,54\% produktu krajowego brutto (PKB). Bieżące wydatki publiczne wyniosły wtedy 90,4 mld PLN i stanowiły 4,55\% PKB oraz $70 \%$ wszystkich nakładów na ochronę zdrowia. Najwięcej wydano na usługi lecznicze - 58,7\%. Następne fundusze poświęcono na artykuły medyczne (w tym leki, $22,7 \%)$, długoterminowa opiekę zdrowotna (6\%), usługi rehabilitacyjne $(4,8 \%)$, profilaktykę i zdrowie publiczne $(2,3 \%)$ oraz administracje i zarzadzanie finansowaniem ochrony zdrowia $(1,8 \%)^{3}$. Dokładny rozkład wydatków prezentuje rysunek 1 .

Na tle innych krajów poziom polskich wydatków na ochronę zdrowia jest stosunkowo niski. W zestawieniu Głównego Urzędu Statystycznego dotyczącego bieżących wydatków na zdrowie w krajach OECD jako procent PKB w 2017 r., Polska znalazła się na siódmym miejscu od końca. Wydatki publiczne wynosiły wtedy 4,5\% PKB, a wydatki prywatne $-2 \% \mathrm{PKB}^{4}$. $Z$ kolei według danych WHO, w 2017 roku rząd RP przeznaczył 4,51\% PKB na prowadzenie polityki zdrowotnej, co dało Polsce szóste miejsce od końca w rankingu 5 .

Centrum Badania Opinii Społecznej (CBOS) w 2018 r. przeprowadziło badanie dotyczące opinii społeczeństwa na temat funkcjonowania opieki zdrowotnej w Polsce. Tylko jedna trzecia ankietowanych pozytywnie oceniła system ochrony zdrowia. Z 66\% badanych

\footnotetext{
2 A. Małodzińska, Narodowy Program Zdrowia wyrazem polskiej publicznej polityki zdrowia, „Zarządzanie Publiczne” 2014, nr 25(1), s. 105-114.

3 Zdrowie i ochrona zdrowia w 2018 r., Główny Urzad Statystyczny, Zakład Wydawnictw Statystycznych, Warszawa-Kraków 2019.

4 Ibidem.

5 Global Spending on Health: A World in Transition, World Health Organization, Geneva 2019.
} 
wypowiadających się negatywnie, 27\% stwierdziło, że kondycja opieki zdrowotnej jest zdecydowanie zła. W porównaniu $z$ badaniem $z$ roku 2016 nastapił wzrost zadowolonych pacjentów o 7 punktów procentowych. W części badania dotyczącej świadczeń i porad otrzymywanych droga powszechnego ubezpieczenia zdrowotnego, $70 \%$ ankietowanych pozytywnie oceniło kompetencje lekarzy, ich dostępność w ramach podstawowej opieki zdrowotnej (68\%) oraz zaangażowanie w wykonywana pracę $(65 \%)$. Najniższe oceny system opieki zdrowotnej otrzymał za dostępność wizyt u lekarzy specjalistów (83\% negatywnych głosów) i niewystarczająca liczbę personelu medycznego w szpitalach (70\%). Połowa respondentów uważała, że problem $z$ jakością i dostępnością świadczeń jest spowodowany zbyt niskimi nakładami środków publicznych na system ochrony zdrowia oraz złym dysponowaniem dostępnymi funduszami ${ }^{6}$.

\section{Rysunek 1}

Wydatki bieżące na ochronę zdrowia w 2017 r.
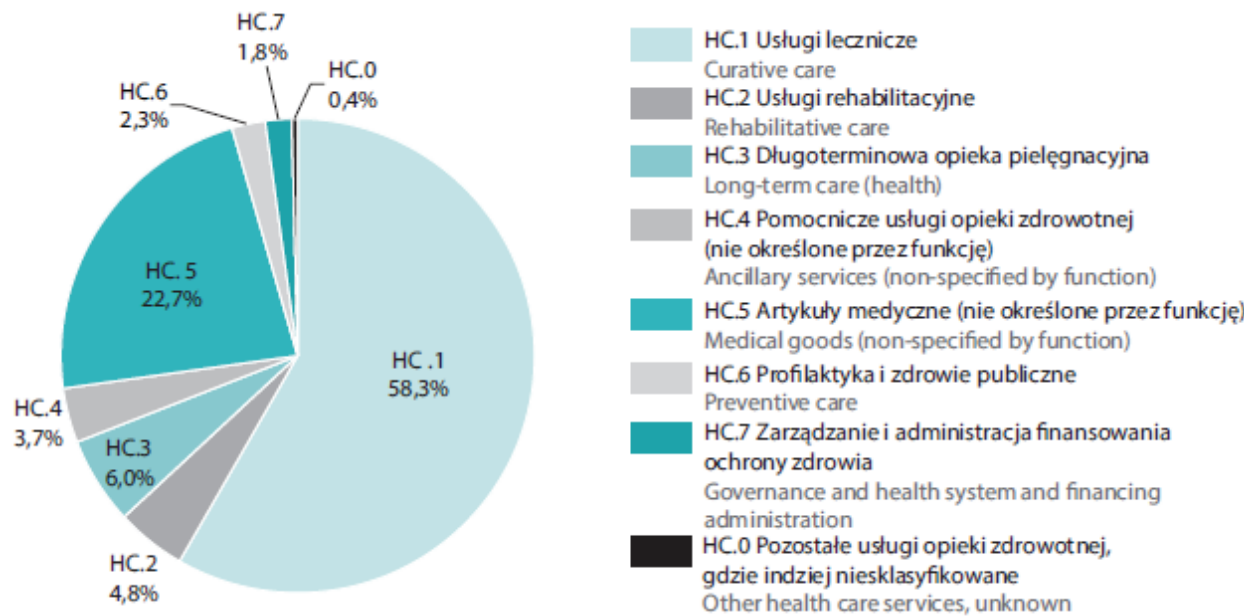

Źródło: Zdrowie i ochrona zdrowia w 2018 r., Główny Urząd Statystyczny, Zakład Wydawnictw Statystycznych, Warszawa-Kraków 2019.

Zdrowie jest jednym $z$ podstawowych dóbr cenionych wśród polskich obywateli. W większości przypadków Polacy są raczej zadowoleni ze swojego stanu zdrowia. Wpływają na to dobre nawyki żywieniowe oraz znaczacy i systematyczny wzrost popularności prozdrowotnego stylu życia. W porównaniu $z$ początkiem lat 90 . w Polsce odnotowano

6 Opinie na temat funkcjonowania opieki zdrowotnej. Komunikat z badań nr 89, Centrum Badania Opinii Społecznej, Warszawa 2018. 
wzrost odsetka osób dbających o zdrowie z 19\% do 64\%. Pomimo dominacji przekonania, że obowiązek ochrony zdrowia spoczywa głównie na ludziach, coraz więcej osób uważa, że o zdrowie obywateli powinno troszczyć się państwo ${ }^{7}$. Polacy niemal powszechnie deklaruja korzystanie $z$ usług zdrowotnych, jednak nie tylko w okresie nagłej choroby. W 2018 r. 88\% badanych przez CBOS deklarowało korzystanie ze świadczeń $\mathrm{w}$ ciagu ostatnich sześciu miesięcy $\mathrm{z}$ powodu złego stanu zdrowia swojego lub dziecka, złożyło wizytę protetykowi lub stomatologowi oraz wykonywało analizę w laboratorium diagnostycznym. 80\% powyższych respondentów $\mathrm{w}$ tym celu skorzystało $\mathrm{z}$ usługi $\mathrm{w}$ ramach powszechnego ubezpieczenia zdrowotnego. Jednak 57\% z nich, pomimo korzystania $z$ usług ogólnodostępnych, posiłkowało się świadczeniami spoza systemu finansowanego lub współfinansowanego przez Narodowy Fundusz Zdrowia. Decydowało się na ten krok głównie $z$ powodu krótszego czasu oczekiwania na wizytę i leczenie ${ }^{8}$.

Grażyna Magnuszewska-Otulak twierdzi, że polska polityka zdrowotna nie jest spójna i konsekwentna ${ }^{9}$. Jest to spowodowane przyjętymi rozwiązaniami systemowymi oraz niemożnościa podjęcia debaty na temat efektywnej polityki zdrowotnej przez kolejne partie rządzące. Polityka zdrowotna powinna zapewnić wyrównanie dostępu do służby zdrowia, jednak dotychczasowe działania prowadza do centralizacji świadczeń specjalistycznych w dużych miastach oraz braku funduszy na prowadzenie punktów medycznych w małych miejscowościach. Rząd powinien rozważyć podniesienie składki zdrowotnej lub zwiększenie udziału finansowania przez gospodarstwa domowe, ponieważ dotychczasowe nakłady publiczne na zdrowie sa zbyt niskie na zaspokojenie potrzeb zdrowotnych ogółu społeczeństwa.

\section{POLITYKA ZDROWOTNA RP W DOBIE PANDEMII COVID-19}

Choroba zakaźna spowodowana koronawirusem SARS-CoV-2 jako epidemia rozpoczęła się w Wuhan (Chiny) w listopadzie 2019 r. WHO uznała ja za pandemię 11 marca 2020 r. (World Health Organization 2020). Do 8 września 2020 r. odnotowano ponad $27 \mathrm{mln}$ przypadków

\footnotetext{
Zdrowie i prozdrowotnej zachowania Polaków. Komunikat z badań nr 138, Centrum Badania Opinii Społecznej, Warszawa 2016.

8 Korzystanie ze świadczeń $i$ ubezpieczeń zdrowotnych. Komunikat $z$ badań $n r$ 97, Centrum Badania Opinii Społecznej, Warszawa 2018.

9 G. Magnuszewska-Otulak, Wybrane problemy polityki zdrowotnej $w$ Polsce, „Problemy Polityki Społecznej. Studia i Dyskusje” 2013, nr 21(2), s. 85-107.
} 
zachorowań w 188 państwach i terytoriach, z czego prawie 900 tys. chorych zmarło, a wyzdrowiało ponad $18 \mathrm{mln}^{10}$. W zwiazku $z$ pandemia podjęto międzynarodowe działania, które mają na celu zapobiegać rozprzestrzenianiu się choroby. Wprowadzono kwarantanny i godziny policyjne, ograniczono podróże, odwołano wiele wydarzeń kulturowych, religijnych i sportowych (np. igrzyska olimpijskie w Tokio w 2020 r.). Część państw wprowadziła ograniczenia ruchu granicznego bądź całkowicie zamknęła granice. Wprowadzono restrykcje dotyczące lotów międzynarodowych i przekraczania granic, kontrole na lotniskach i dworcach kolejowych. Szkoły i uniwersytety w większości państw przeszły w tryb nauki zdalnej, w miarę możliwości przeniesiono pracowników $z$ biur do domów. Pandemia stała się przyczyną globalnych zakłóceń gospodarczych i społecznych, wywołując największą recesję od czasów wielkiego kryzysu.

W Polsce przygotowania do walki $z$ pandemia rozpoczęto $\mathrm{w}$ styczniu 2020 roku. Najpierw wprowadzono specjalne procedury dla pasażerów przylatujących $z$ Chińskiej Republiki Ludowej oraz rozpoczęto badania laboratoryjne osób podejrzanych o zakażenie wirusem. Główny Inspektorat Sanitarny ostrzegał przed podróżami do państw z licznymi ośrodkami zachorowań, takich jak Włochy czy Korea Południowa. W szpitalach wprowadzono zakaz odwiedzin. Zabroniono wywożenia $z$ Polski leków mogacych pomóc $w$ walce $z$ chorobą oraz zwolniono spirytus $z$ akcyzy. Na początku marca Polska przyłączyła się do funkcjonującego w Unii Europejskiej mechanizmu wspólnych przetargów kryzysowych zakupów środków ochronnych, szczepionek i leków ${ }^{11}$.

Pierwszy oficjalny przypadek zachorowania na COVID-19 w Polsce odnotowano 4 marca 2020 r. w Zielonej Górze ${ }^{12}$. W tym czasie na terenie kraju funkcjonowało trzynaście placówek laboratoryjnych, w których badano próbki na obecność SARS-CoV-2, m.in.: Wojewódzki Szpital Zakaźny w Warszawie, Narodowy Instytut Zdrowia Publicznego - Państwowy Zakład Higieny w Warszawie oraz laboratoria w Kielcach, Gdańsku, Rzeszowie, Katowicach, Poznaniu, Wrocławiu

10 COVID-19 Dashboard by the Center for Systems Science and Engineering (CSSE) at Johns Hopkins University (JHU), Johns Hopkins University, https://www.arcgis.com/ apps/opsdashboard/index.html\#/bda7594740fd40299423467b48e9ecf6 [dostęp: 8 września 2020].

11 T. Bielecki, Czy Unia Europejska robi za mało $w$ sprawie koronawirusa? wyborcza. pl, https://wyborcza.pl/7,75399,25786156,czy-unia-europejska-robi-za-malo-w-sprawiekoronawirusa.html\#S.main_topic-K.C-B.1-L.2.duzy [dostęp: 9 czerwca 2020].

12 Pierwszy przypadek koronawirusa w Polsce, Ministerstwo Zdrowia, https: / / www.gov. pl/web/zdrowie/pierwszy-przypadek-koronawirusa-w-polsce [dostęp: 5 września 2020]. 
i Olsztynie. W dniach od 14 do 20 marca 2020 r. obowiazywał w kraju stan zagrożenia epidemicznego, a od 15 marca 2020 r. wprowadzono kordon sanitarny, który znacznie ograniczył ruch graniczny. Od 20 marca 2020 r. obowiazuje w Polsce stan epidemii. Do kolejnych działań, które podjęto $\mathrm{w}$ ramach walki $\mathrm{z}$ pandemią, należały:

- odwołanie imprez masowych powyżej 1000 osób w zamkniętych pomieszczeniach;

- przejście uczelni wyższych na tryb nauczania zdalnego;

- zamknięcie szkół, przedszkoli, żłobków etc. (w przypadku szkół zaimplementowano nauczanie zdalne);

- czasowe zamknięcie granic drogowych, kolejowych i lotniczych, $z$ wprowadzeniem obowiązkowej kwarantanny dla osób przekraczajacych granicę droga lądową;

- wdrożenie kar grzywny oraz pozbawienia wolności za złamanie zasad kwarantanny;

- wprowadzenie czasowego zakazu przemieszczania się (z wyjątkami);

- czasowy zakaz zgromadzeń powyżej dwóch osób;

- wprowadzono ograniczenia w poruszaniu się komunikacją miejska;

- czasowo zamknięto bulwary, plaże, parki, place zabaw etc.;

- nakaz noszenia maseczek ochronnych w zamkniętych przestrzeniach publicznych.

Na koniec kwietnia 2020 r. Centrum Badania Opinii Społecznej przeprowadziło badanie dotyczace stosunku społeczeństwa do restrykcji i epidemii. Dokonano go wśród społeczności internetowej. Blisko $60 \%$ ankietowanych miało poczucie, że pandemia COVID-19 jest czymś bezprecedensowym. Pozostali uważali COVID-19 za kolejną chorobę sezonowa i nie traktowali jej za coś niezwykłego. O wyjatkowości epidemii były przekonane osoby starsze, mieszkańcy największych miast oraz osoby $z$ wyższym wykształceniem. Większość respondentów $(78 \%)$ przestrzegała ograniczeń dotyczacych kontaktów międzyludzkich i wychodzenia $z$ domu. co mogło świadczyć o ich obawach przed zakażeniem. Znaczna część badanej społeczności aprobowała wysokie kary za łamanie nowych zasad. Jednak większość ankietowanych $z$ rezerwa podchodziła do tych przepisów, uważając, że sa zbyt nieprecyzyjne, co z kolei może prowadzić do nadużyć. Podsumowując, na początkowym etapie pandemii społeczeństwo akceptowało nowe zalecenia rządu ${ }^{13}$.

13 Opinie o epidemii koronawirusa $i$ zwiazanych $z$ nia restrykcjach. Komunikat $z$ badań nr 58, Centrum Badania Opinii Społecznej, Warszawa 2020. 
Szybkość rozprzestrzeniania COVID-19 wymusiła wdrożenie działań, które często były chaotyczne lub tymczasowe. Powodowały drastyczna zmianę trybu życia wielu grup społecznych. Ze względu na szczególnie niekorzystny wpływ wirusa na osoby starsze, seniorom w znacznym stopniu ograniczono aktywność życiową. Długoterminowe izolowanie w domach może skutkować pogorszeniem stanu zdrowia osób starszych, dla których ruch oraz spotkania towarzyskie sa istotnym elementem budowania ich zdrowia i samopoczucia. Należy również opracować nowe procedury i standardy domów pomocy społecznej. Obecnie nie sa one dostosowane do faktycznej funkcji tych instytucji, czyli opieki nad osobami wymagającymi wzmożonego nadzoru medycznego. Właśnie w domach pomocy społecznej znajdowało się wiele ognisk epidemii, $z$ którymi pracownicy nie potrafili sobie poradzić. Podczas pandemii cierpią też osoby $z$ niepełnosprawnościami, które zostały pozbawione możliwości kontynuowania terapii zajęciowych. Wpływa to negatywnie na ich stan zdrowia, jak również zwiększa ryzyko wystapienia kryzysów psychicznych w rodzinach pozbawionych zinstytucjonalizowanego wsparcia. Podobnie wygląda kwestia pacjentów onkologicznych. Ci, którzy zostali już zdiagnozowani, maja kontynuowane leczenie. Jednak utrudniona sytuację maja osoby $z$ podejrzeniem choroby nowotworowej. W ich przypadku najważniejszy jest czas - im szybciej zostaną wykonane badania specjalistyczne i nowotwór zostanie potwierdzony, tym większe sa ich szanse na wyleczenie. Obecna sytuacja znacznie wydłużyła czas wykonywania procedur diagnostycznych ${ }^{14}$.

Pandemia wprowadziła chaos praktycznie w każdym aspekcie funkcjonowania państwa. Wymusiła przeorganizowanie logistyki, transportu, stosunków międzynarodowych, relacji gospodarczych, a przede wszystkim systemu ochrony zdrowia. Najwyraźniej pokazuje to tzw. specustawa koronawirusowa, czyli Ustawa $z$ dnia 2 marca 2020 r. o szczególnych rozwiązaniach związanych z zapobieganiem, przeciwdziałaniem i zwalczaniem COVID-19, innych chorób zakaźnych oraz wywołanych nimi sytuacji kryzysowych (Dz.U. 2020, poz. 1423 z późn. zm.). Ustalono w niej zasady zapobiegania i zwalczania zakażenia wirusem SARS-CoV-2, funkcje administracji publicznej i obywateli $\mathrm{w}$ walce $z$ choroba oraz reguły pokrywania kosztów reali-

14 Rekomendacje Rady Ekspertów przy Rzeczniku Praw Pacjenta: Ochrona zdrowia $w$ czasie epidemii, Rzecznik Praw Pacjenta, https://www.gov.pl/web/rpp/ochrona-zdrowia -w-czasie-epidemii-rekomendacje-rady-ekspertow-przy-rzeczniku-praw-pacjenta [dostęp: 6 września 2020]. 
zacji powyższych działań. Poprzez akt prawny wprowadzono zmianę w czternastu innych ustawach, m.in. o zawodach lekarza i lekarza dentysty, o Państwowej Inspekcji Sanitarnej, o zawodzie fizjoterapeuty, o zawodach pielęgniarki i położnej, o publicznej służbie krwi, o Agencji Badań Medycznych, Prawo farmaceutyczne, o Państwowym Ratownictwie Medycznym, o zapobieganiu i zwalczaniu zakażeń i chorób zakaźnych u ludzi.

Jedna ze zmian wprowadzona przez specustawę jest wydłużenie marcowej listy refundacyjnej do końca sierpnia 2020 r. Kolejna nowość dotyczy uproszczonego powrotu do czynnego wykonywania zawodu przez położne i pielęgniarki, które miały minimum 5-letnia przerwę w karierze zawodowej. Jest to odpowiedź na zbyt niską liczbę personelu, która dodatkowo w każdej chwili może zostać uszczuplona przez kwarantannę. Ustawa wprowadziła również zmiany i dodatkowe możliwości w organizacji pracy podmiotów leczniczych:

- uproszczenie prowadzenia dokumentacji medycznej;

- możliwość wykonywanej ponadwymiarowej, dodatkowej pracy w podmiotach leczniczych przez pracowników wykonujących zawód medyczny, w tym wykorzystywanie tzw. klauzuli opt-out;

- zatrudnienie pracownika medycznego odbywajacego kwarantannę w ramach pracy zdalnej, przy jednoczesnym braku ryzyka utraty dodatkowego zasiłku opiekuńczego;

- uzyskanie zasiłku chorobowego w wymiarze 100\% podstawy wynagrodzenia przez pracowników medycznych, którzy zostali objęci kwarantanna $z$ powodu styczności $z$ osobami zakażonymi $\mathrm{w}$ ramach obowiązków zawodowych ${ }^{15}$.

Powyższe zmiany w organizacji pracy placówek medycznych maja na celu optymalne wykorzystanie ograniczonych zasobów ludzkich. Po zalegalizowaniu ustawy, możliwe stało się wydłużenie czasu pracy (i stosownego wynagrodzenia) nie tylko pracowników podmiotów leczniczych $z$ wyższym wykształceniem, ale również tych $z$ innym poziomem kwalifikacji oraz pracowników takich placówek, jak regionalne centra krwiodawstwa czy Państwowa Inspekcja Sanitarna. W ramach nowej ustawy przesunięte zostały egzaminy w zawodach medycznych oraz rekrutacje na specjalizacje. Możliwe stało się skierowanie lekarza stażysty do wykonywania zadań przy zwalczaniu epidemii, przy jednoczesnym wliczeniu tego czasu do okresu odbywania stażu i szko-

15 Walka z koronawirusem. Sejm uchwalił zmiany w 14 „zdrowotnych” ustawach, GazetaPrawna.pl, https://serwisy.gazetaprawna.pl/zdrowie/artykuly/1464626,koronawirus -w-polsce-ustawa-tarcza-antykryzysowa.html [dostęp: 6 września 2020]. 
lenia specjalizacyjnego. Farmaceuci uzyskali prawo do wystawiania tzw. recepty farmaceutycznej w przypadku zagrożenia zdrowia i życia pacjenta. Wspomniana grupa pozyskała też możliwość wystawiania recept pro auctore i pro familiae. Ustawa wpłynęła również na przyspieszenie i usprawnienie inwestycji w sektorze ochrony zdrowia dzięki m.in. wyłączeniu procedury opiniowania inwestycji pod kątem ich celowości (IOWISZ). W akcie wprowadzono dodatkową instytucję, jaka jest izolacja w warunkach domowych. Stosuje się ją wobec osób o lekkim przebiegu choroby, bez konieczności hospitalizacji. W ten sposób zwiększono dostępna bazę łóżek szpitalnych dla osób o ostrym przebiegu COVID-19. Reguły dotyczace izolacji domowej i kwarantanny oparte sa na wytycznych ECDC w zakresie oceny ryzyka zwalczania zakażeń na obszarze Europy i krajów UE ${ }^{16}$.

Zasadność i efektywność zmian wprowadzonych przez specustawę moga obrazować badania CBOS z lipca i sierpnia 2020 r. W lipcowym badaniu $30 \%$ respondentów zadeklarowało, iż z powodu epidemii odwołano bądź przełożono jego wizytę u lekarza specjalisty. $Z$ kolei wizyty u lekarza internisty i lekarza podstawowej opieki zdrowotnej odwołano u 24\% ankietowanych. Odmówienia przyjęcia na Szpitalnym Oddziale Ratunkowym doświadczyło jedynie 1\% badanych spośród 13\%, których dotyczyła ta kwestia. Podsumowujac, ponad $40 \%$ respondentów odczuło niedogodności z tytułu dostępu do opieki medycznej. Objawiały się jako: odwoływane i przekładane wizyty, zabiegi, badania, przyjęcia na leczenie szpitalne, problemy z pozyskaniem zwolnień lekarskich i recept oraz ogólne trudności w dostępie do usług medycznych. Paradoksalnie, w tamtym czasie odsetek Polaków zadowolonych $\mathrm{z}$ funkcjonowania systemu ochrony zdrowia był o 6 punktów procentowych wyższy niż w 2018 r. (36\%), zaś nieusatysfakcjonowanych - o 8 pp. mniej niż w 2018 r. (58\%) ${ }^{17}$. Niestety, stosunek osób niezadowolonych do zadowolonych jest wciąż korzystniejszy dla pierwszej grupy.

Rozprzestrzenienie się wirusa SARS-CoV-2 znacznie wpłynęło na sposób korzystania $z$ usług opieki zdrowotnej w Polsce. Porównując dane z 2018 r. oraz z lipca 2020 r., CBOS stwierdza, że „wyraźnie przybyło w ogóle nieleczących się i niebadających się (z 12\% do 30\%), a zdecydowanie ubyło korzystających ze świadczeń medycznych w sposób „mieszany” - zarówno w ramach powszechnego ubezpiecze-

\footnotetext{
16 Ibidem.

17 Opieka medyczna $w$ czasie pandemii. Komunikat $z$ badań $n r$ 88, Centrum Badania Opinii Społecznej, Warszawa 2020.
} 
nia zdrowotnego, jak i poza nim (z 48\% do 28\%)"18. Odnotowano ogólny spadek korzystania $z$ porad lekarzy pierwszego kontaktu, lekarzy specjalistów, badań diagnostycznych i laboratoryjnych oraz leczenia stomatologicznego. W niewielkim stopniu przybyło ludzi badajacych się i leczących się wyłącznie w ramach dodatkowego ubezpieczenia lub za pieniądze $z$ domowego budżetu. Powyższe dane moga być odpowiedzia na utrudniony dostęp do świadczeń medycznych w ramach powszechnego ubezpieczenia zdrowotnego.

Pandemia SARS-CoV-2 w znacznym stopniu przyczyniła się do „odkrycia” telemedycyny. Tego rodzaju usługi sa od wielu lat dostępne w Polsce, jednak nie były popularne. Telemedycynę traktowano jako ciekawostkę, odnoszono się do niej z rezerwą. Podczas pierwszych miesięcy epidemii Polacy najczęściej konsultowali się z lekarzami telefonicznie bądź on-line. W głównej mierze była to zasługa tzw. e-recept i e-zwolnień, które cieszą się wciąż rosnąca popularnością ${ }^{19}$. Potrzebę świadczeń telemedycznych doceniła również Komisja Europejska, która dofinansowała platformę e-zdrowie kwotą 120 mln PLN. Dzięki tej sumie system informatyczny został zaktualizowany i rozszerzony o nowe funkcjonalności. Jedna $z$ nich jest projekt zapisu on-line na teleporadę, którego formularz można znaleźć na stronie pacjent.gov.pl. Jest on przeznaczony dla osób, które podejrzewają u siebie COVID-19 i potrzebuja konsultacji lekarskiej. Pacjenci moga skorzystać z wideo-konsultacji z pracownikiem medycznym. System pozwala na połaczenie dowolnego, zarejestrowanego przez formularz pacjenta $z$ lekarzem lub innym pracownikiem medycznym. Dzięki temu personel medyczny może udzielać konsultacji w warunkach domowych, dzięki czemu moga pracować, przebywając w obowiazkowej izolacji. Po konsultacji pacjent może otrzymać poprzez sms lub e-mail powiadomienie o kolejnych etapach leczenia. W tym samym czasie moga być raportowane zanonimizowane dane na potrzeby systemu ochrony zdrowia. System umożliwia generowanie raportów analitycznych, które śledzą dane o czasie obsługi pacjenta, czasie oczekiwania i o kolejkach oczekujaccych. W celach analitycznych system może także generować dane na temat rozkładu zgłoszeń z przypisaniem ich lokalizacji do mapy, co w przyszłości może być pomocne m.in przy wczesnym wykrywaniu kolejnych ognisk choroby ${ }^{20}$.

\footnotetext{
18 Korzystanie ze świadczeń i ubezpieczeń zdrowotnych. Komunikat $z$ badań nr 98, Centrum Badania Opinii Społecznej, Warszawa 2020.

19 Opieka medyczna $w$ czasie pandemii..., s. 4-5.

20 Telemedycyna wychodzi na prowadzenie, Polityka Zdrowotna, https://www.politykazdrowotna.com/57910,telemedycyna-wychodzi-na-prowadzenie [dostęp: 6 września 2020].
} 
W lipcu 2020 r. Główny Inspektor Sanitarny wydał nowe wytyczne dotyczące schematu postępowania w placówkach podstawowej opieki zdrowotnej oraz nocnej i świattecznej opieki zdrowotnej w czasie pandemii COVID-19. Pierwsze zalecenia pochodza $z$ marca $2020 \mathrm{r}$. Lipcowa aktualizacja przedstawiła teleporady jako podstawowa formę udzielania świadczeń przez lekarzy pierwszego kontaktu. Każdy pacjent, bez względu na wykazywanie cech infekcji górnych dróg oddechowych bądź ich brak, powinien zostać przyjęty w ramach konsultacji telefonicznej /online. Wizyta stacjonarna odbywa sie jedynie w sytuacji, gdy jest to niezbędne. Lekarze moga wystawić zwolnienie lekarskie na podstawie przeprowadzonej teleporady. Jeżeli specjalista stwierdzi podejrzenie zakażenia SARS-CoV-2 bądź zachorowania na COVID-19, ma obowiazek zapewnić transport pacjenta do jednostki diagnozującej i leczącej chorych na koronawirusa. Dodatkowo lekarz POZ powinien zgłosić COVID-19 właściwemu państwowemu powiatowemu inspektorowi sanitarnemu ${ }^{21}$.

Teleporady nie sa pozbawione wad, dlatego nie można uznać ich za idealna formę komunikacji $z$ lekarzem. Przede wszystkim zdalny charakter konsultacji utrudnia przeprowadzenie badania klinicznego. Jest to szczególnie dotkliwie odczuwane przez ortopedów czy laryngologów. Pacjenci nie znaja żargonu medycznego, często nie potrafia dokładnie opisać problemu, który sprowadza ich do specjalisty. $Z$ tego powodu diagnoza może być zbyt ogólna bądź błędna. Kolejną wada teleporady jest brak możliwości oceny badań obrazowych i skonfrontowania ich $z$ rzeczywistym wyglądem pacjenta. Przejście na tryb zdalny sprawiło, że pacjent ma utrudniony dostęp do ambulatorium, gdzie doraźnie można podać zastrzyk z lekiem przeciwbólowym czy opatrzeć ranę. Pacjenci ambulatoryjni obecnie zgłaszają się na SOR-y, co jest niekorzystne ze względu na ich przepełnienie. To $z$ kolei prowadzi do zwiększenia ryzyka zakażenia się COVID-19. Ważna jest również kwestia bezpieczeństwa tajemnicy lekarskiej. W trybie stacjonarnym pacjent ma pewność, że informacja na temat jego stanu zdrowia nie opuści gabinetu lekarskiego. W przypadku konsultacji zdalnych nie każdy zdaje sobie sprawę $z$ potrzeby szyfrowania połączeń. Same przychodnie również zapominają o wadze bezpieczeństwa cyfrowego, co rodzi ryzyko przekazania wrażliwych danych nieodpowiednim osobom. Ciemna strona telemedycyny jest również ewentualna bariera

${ }^{21}$ Podejrzenie zakażenia koronawirusem - wytyczne GIS, Naczelna Izba Lekarska, https://nil.org.pl/aktualnosci/4955-podejrzenie-zakazenia-koronawirusem-wytyczne-gis [dostęp: 9 października 2020]. 
technologiczna, zwłaszcza wśród osób starszych. Nie każdy posiada dostęp do komputera $z$ kamera i bardzo dobrym pasmem internetowym. $Z$ kolei rozmowa telefoniczna czasami bywa niewystarczająca.

Ograniczony dostęp do świadczeń szczególnie odczuły osoby leczone onkologicznie, pacjenci po udarach i zawałach oraz chorzy $z$ cukrzyca i innymi chorobami przewlekłymi. Od początku pandemii do Rzecznika Praw Pacjenta wpłynęło wiele skarg od powyższych grup pacjentów. Dotyczyły one braku możliwości konsultacji stanu zdrowia, przedłużenia recept oraz otrzymania sprzecznych zaleceń. Jednym $z$ powodów takiego stanu był brak jasnych zaleceń dotyczacych chorych, którzy nie zachorowali na COVID-19 bądź pacjentów, u których podejrzewa się koronawirusa, ale potrzebuja pilnej pomocy kardiologicznej czy onkologicznej ${ }^{22}$. Trudną sytuację miały również osoby $z$ podejrzeniem choroby onkologicznej, u których czas przeprowadzenia diagnostyki jest krytycznym czynnikiem całego procesu leczenia. Badanie fundacji Onkologia 2025 wykazało, że w poczatkowej fazie pandemii prawie każda dziedzina onkologii odnotowała spadek liczby pacjentów oraz zrealizowanych świadczeń. Wpływ reżimu sanitarnego odczuły wszystkie etapy ścieżki pacjenta onkologicznego. Najbardziej zaniedbanym obszarem onkologii podczas pandemii stała się profilaktyka. Ze względów sanitarnych drastycznie zredukowano takie procedury, jak mammografia czy kolonoskopia (dane $z$ maja i czerwca pokazuja spadki na poziomie $80-90 \%)^{23}$.

Obecne wytyczne (stan na poczatek września 2020 r.) dotyczace walki z pandemia w Polsce wymieniono poniżej. Sa następstwem obserwacji dotychczasowej sytuacji oraz próbą naprawy popełnionych wcześniej błędów.

- Regionalizacja powiatów poprzez podział na strefy zielone (dotychczasowe procedury bezpieczeństwa), żółte (dodatkowe ograniczenia) i czerwone (najwyższy stopień obostrzeń). Podział na strefy jest uzależniony od wzrostu liczby zakażeń w wyższym stopniu niż w pozostałej części kraju.

${ }^{22}$ M. Zieleniewska, Chorzy na nowotwory $i$ serce byli $w$ pandemii pozostawieni sami sobie. Innym wydawano sprzeczne zalecenia. Kto jest temu winny?, https://www.medonet. pl/koronawirus / koronawirus-w-polsce, chorzy-na-nowotwory-i-serce-byli-w-pandemii-pozostawieni-sami-sobie--innym-wydawano-sprzeczne-zalecenia--kto-jest-temu-winny-, artykul,01684409.html [dostęp: 10 października 2020].

23 Onkologia $w$ czasach COVID-19. Jak pandemia zmieniła dostepność do opieki onkologicznej? Onkologia 2025, http://onkologia2025.pl/userfiles/321321321/onkologia/ COVID19/Onkologia\%20w\%20czasach\%20COVID-19\%20raport.pdf [dostęp: 10 października 2020]. 
- Ograniczenia w przemieszczaniu się - należy utrzymywać min. 1,5 metra odległości pomiędzy pieszymi (z określonymi wyjątkami).

- Zasłanianie ust i nosa w miejscach publicznych, gdzie niemożliwe jest zachowanie 1,5-metrowej odległości między pieszymi, np. w szkole, w komunikacji miejskiej, w kinie.

- Kwarantanna dla osób, które przekraczały granicę Polski stanowiącą zewnętrzna granicę Unii Europejskiej, mieszkają z osoba, która podlega kwarantannie lub miały kontakt $z$ (potencjalnie) zakażonymi. Jeśli u osoby podlegającej kwarantannie nie wykryto wirusa, odosobnienie trwa 10 dni. W tym czasie bezwzględnie nie może opuszczać miejsca odbywania kwarantanny.

- Ograniczenia liczby osób uczestniczacych w zgromadzeniach i imprezach w zależności od aktualnego „koloru” danego powiatu.

- Ograniczenie liczby osób korzystajacych ze środków komunikacji publicznej.

- Ograniczenie przekraczania zewnętrznej granicy Unii Europejskiej przez cudzoziemców.

- Zakaz lądowania samolotów cywilnych na określonym terytorium (aktualna lista znajduje się na internetowych stronach rządowych).

- Lokale gastronomiczne, salony kosmetyczne i fryzjerskie, salony tatuażu i piercingu, hotele, siłownie, baseny funkcjonują w reżimie sanitarnym ${ }^{24}$.

W pierwszych dniach września 2020 r. Ministerstwo Zdrowia przedstawiło strategię walki z pandemia COVID-19 na jesień $2020 \mathrm{r}$. Jest to podsumowanie najważniejszych zmian kierunkowych, jakie zostana podjęte podczas walki $z$ wirusem. Przewiduje się, że okres jesienno-zimowy będzie trudny ze względu na sezonowy wzrost zachorowań na grypę i infekcje grypopodobne. $Z$ tego względu postawiono na zmianę podejścia do walki $z$ pandemią. Fundamentem nowej filozofii jest stosowanie działań dopasowanych do danego regionu, a nie całego kraju. Natężenie działań ochronnych będzie dostosowywane do występującego ryzyka zakażeń w danym regionie. Środki zaradcze będa adekwatne do skali ryzyka.

Nowa strategie działania podzielono na cztery segmenty. Pierwszy dotyczy zmian organizacyjnych w celu zwiększenia wykorzystania zasobów ludzkich i infrastrukturalnych, wzrostu zdolności do testowania

${ }^{24}$ Koronawirus - informacje i zalecenia, https://www.gov.pl/web/koronawirus/aktualne-zasady-i-ograniczenia [dostęp: 6 września 2020]. 
oraz usprawnienia działania inspekcji sanitarnej. W ramach tej części strategii dojdzie do odejścia od koncepcji szpitali jednoimiennych na rzecz utworzenia trzech poziomów zabezpieczenia szpitalnego:

- poziom I - wydzielenie miejsc we wszystkich szpitalach należących do sieci szpitali, które umożliwia przyjęcie pacjenta $z$ podejrzeniem COVID-19 do czasu otrzymania wyniku testu oraz podjęcie zabiegów ratujących życie;

- poziom II - zapewnienie miejsc do leczenia pacjentów z COVID-19 w oddziałach zakaźnych/obserwacyjno-zakaźnych;

- poziom III - zredukowanie obecnej liczby szpitali wielospecjalistycznych dla pacjentów z COVID-19 do dziewięciu oraz zwiększenie liczby zespołów transportowych.

Dodatkowo w ramach tego segmentu planowana jest rozbudowa sieci mobilnych punktów wymazu, włączenie lekarzy POZ do zlecania testów oraz elektronizacja zgłoszeń o osobach zagrożonych zakażeniem do inspekcji sanitarnych ${ }^{25}$.

Drugi segment strategii dotyczy testowania. Rząd zamierza skoncentrować się na przeprowadzaniu testów wśród pacjentów $z$ objawami charakterystycznymi dla COVID-19, takich jak duszność czy gorączka. Kolejnym celem tego segmentu jest ochrona osób z grup ryzyka, czyli seniorów, osób $z$ obniżona odpornością bądź rezydentów jednostek opieki całodobowej. Docelowo testom będa podlegać wszystkie osoby $z$ objawami, osoby przed rozpoczęciem turnusu rehabilitacyjnego oraz pacjenci bezobjawowi $\mathrm{w}$ toku dochodzenia epidemiologicznego. W szpitalnych oddziałach ratunkowych mają być dostępne szybkie testy (w tym testy antygenowe) do diagnozy pacjentów $z$ objawami ${ }^{26}$.

Kolejna część strategii walki z COVID-19 dotyczy prewencji, która ma ograniczyć rozprzestrzenianie się wirusa oraz ograniczenie osób chorych na grypę. $Z$ tego względu osoby powyżej 75 roku życia, pracownicy ochrony zdrowia i farmaceuci otrzymaja możliwość bezpłatnych szczepień przeciwko grypie. Wciąż obowiązują dystans społeczny, dezynfekcja i maseczki. Ostatnia część dokumentu to zbiór nowych, najważniejszych schematów postępowania, takich jak: właczenie $\mathrm{POZ}$ do systemu testowania, algorytm postępowania w sytuacji podejrzenia COVID-19 - transport własny i przekazanie $z$ POZ, zwolnienie $z$ kwarantanny czy zwolnienie $z$ izolacji domowej27.

25 Strategia walki z pandemia COVID-19-jesień 2020, Ministerstwo Zdrowia, https:// www.gov.pl/web/gis/strategia-walki-z-pandemia-covid-19 [dostęp: 7 września 2020].

26 Ibidem.

27 Ibidem. 


\section{PIERWSZY ETAP WALKI Z PANDEMIĄ COVID-19 W WIELKIEJ BRYTANII}

Pierwsze przypadki COVID-19 w Wielkiej Brytanii odnotowano w drugiej połowie stycznia 2020 r. Dane na dzień 6 września 2020 r. pokazuja, że w Zjednoczonym Królestwie wykryto ponad 347 tys. zachorowań oraz 41,5 tys. zgonów spowodowanych pandemią ${ }^{28}$. Ponad 90\% zmarłych posiadało choroby współistniejące bądź żyło ponad 60 lat. Odnotowano duże zróżnicowanie występowania ognisk choroby w zależności od regionu, w których były zlokalizowane. W tym miejscu warto wspomnieć, że Anglia, Irlandia Północna, Szkocja i Walia posiadaja odrębne systemy opieki zdrowotnej, które sa finansowane ze środków publicznych, oddzielne rządy i parlamenty, sektor prywatny oraz dobrowolne świadczenia. $Z$ tego względu każdy region posiada inna politykę i priorytety zdrowotne ${ }^{29}$.

W pierwszych tygodniach epidemii, włodarze Wielkiej Brytanii odrzucili tzw. lockdown, który w tym czasie podjęły już Włochy, Hiszpania czy Francja. Nie dostosowano się do wytycznych WHO, które mówiły o znajdowaniu, testowaniu, leczeniu i izolowaniu chorych. Ruch międzynarodowy pozostał nieograniczony. Zakup i dostawa zasobów testowych były nieskuteczne pomimo gotowego testu wirusowego i ofert pomocy ze strony laboratoriów uniwersyteckich i sektora prywatnego $^{30}$. Brytyjscy specjaliści liczyli na zbudowanie przez społeczeństwo tzw. odporności stadnej, dlatego w czasie ogólnoświatowego lockdown na Wyspach szkoły były otwarte, a starsze osoby wypisywane ze szpitali do domów opieki bez testów na SARS-CoV-2.

Nakaz pozostania w domu, zredukowanie podróży do niezbędnego minimum, zakaz kontaktów $z$ osobami spoza gospodarstwa domowego oraz nakaz zamknięcia szkół, firm, lokali gastronomicznych etc. wydano dopiero w marcu 2020 r. Zarekomendowano izolację domowa osobom z objawami COVID-19 oraz tym, których odporność jest niska ze względu na inne choroby. Policja została upoważniona do egzekwowania dostosowania się społeczeństwa do nowych zaleceń. Z kolei ustawa o koronawirusie z 2020 r. nadała rzadowi nadzwyczajne

${ }^{28}$ COVID-19 Dashboard... .

${ }_{29}$ How is the NHS structured? The King's Fund, https:/ / www.kingsfund.org.uk/audiovideo/how-is-nhs-structured-funding-flow [dostęp: 10 października 2020].

${ }^{30}$ P. Clarc, C. Cookson, L. Hughes, How the UK got coronavirus testing wrong, „Financial Times”, 27 marca 2020, https://www.ft.com/content/fa747fbd-c19e-4bac-9c37-d46 afc9393fb [dostęp: 10 października 2020]. 
uprawnienia, które nie były stosowane od czasu II wojny światowej. Szpitale nie były przygotowane na taką sytuację, brakowało sprzętu ochrony indywidulanej oraz wolnych łóżek. W kwietniu 2020 r. tylko $12 \%$ lekarzy pracujaccych w szpitalach czuło się w pełni chronionych przed wirusem w pracy, ponieważ liczba zgonów personelu opieki zdrowotnej i opieki społecznej w tamtym czasie stale rosła ${ }^{31}$.

Brytyjski system opieki zdrowotnej, posiadajacy jedna $z$ najlepszych reputacji na świecie, nie był w stanie zapobiec śmierci tysięcy obywateli w pierwszej fazie pandemii. Według Gabriela Scally'ego i współautorów do przyczyn tego stanu należą m.in. ${ }^{32}$ :

- W grupie ciała doradczego i zarządzającego polityka zdrowotna w czasie COVID-19 zasiadali epidemiolodzy i analitycy. Zabrakło w niej ekspertów zdrowia publicznego, chorób zakaźnych oraz przedstawicieli mniejszości. Brak niezależnych, naukowych opinii doprowadził do podejmowania błędnych decyzji w początkowej, krytycznej fazie rozprzestrzeniania się wirusa.

- Reorganizacja systemu z 2012 r. spowodowała utratę wartościowych organów i stanowisk. Zlikwidowano Agencję Ochrony Zdrowia, regionalne zespoły zdrowia publicznego i regionalne obserwatoria zdrowia publicznego, a pozostałości włączono do odchudzonej agencji Departamentu Zdrowia (Public Health England). Nowa agencja nie ma niezależnego głosu i wyraźnego przywództwa w dziedzinie zdrowia publicznego.

- Na początku pandemii tylko jedno $z$ czterech terytoriów Wielkiej Brytanii posiadało wyszkolonego lekarza zdrowia publicznego jako lidera. Dodatkowo od czasu reformy z 2012 r. środki na ochronę zdrowia uległy znacznej redukcji, co doprowadziło do braku personelu specjalizującego się w chorobach zakaźnych i sytuacjach kryzysowych.

Sytuacja w Wielkiej Brytanii została względnie opanowana latem 2020 r. Wpływ na redukcję kryzysu miały następujace czynniki: przestrzeganie zasad dystansu społecznego, izolowanie osób starszych, wsparcie szpitali poprzez zwiększenie bazy łóżkowej oraz zmobilizowanie do pracy wszelkiego dostępnego personelu medycznego.

${ }^{31}$ G. Scally, B. Jacobson, K. Abbasi, The UK's public health response to covid-19, „BMJ” 2020, nr 369(1932), https://www.bmj.com/content/369/bmj.m1932.full [dostęp: 10 października 2020].

32 Ibidem. 


\section{PODSUMOWANIE}

Pandemia COVID-19 obnażyła zapaść, w jakiej znajduje się polityka zdrowotna w Polsce. W jej początkowej fazie brakowało testów oraz podstawowych środków ochrony. Lokalni mieszkańcy przeprowadzali zbiórki na rzecz kupna maseczek i fartuchów ochronnych, zakłady kosmetyczne i tatuażyści przekazywali szpitalom swoje jednorazowe rękawiczki. Widoczny był chaos, nieskoordynowane działania oraz problemy proceduralne. Działania rzadu były odpowiedzia na nagłe potrzeby, a nie zaplanowanym działaniem. Jaskrawe i dobrze widoczne stały się takie kwestie, jak niedofinansowanie systemu, znaczne braki w kadrach zawodów medycznych oraz konieczność reform. Wszystkie siły skoncentrowano na walce $z$ wirusem, zapominając o "standardowych” pacjentach. $Z$ tego względu znacznie wydłużył się czas oczekiwania na przyjęcia planowe oraz wykonanie specjalistycznych usług medycznych. Podobnie wyglądała poczatkowa faza walki z pandemia w Wielkiej Brytanii. Brytyjczycy, po pierwszej fazie „bagatelizowania” COVID-19, w dosyć chaotyczny sposób próbowali wprowadzić ład w społeczeństwie i zatrzymać rozwój choroby. Można przypuszczać, że znaczna większość systemów zareagowała podobnie - poczatkowo $z$ pewnym niedowierzeniem, by następnie gwałtownie i niesystematycznie wprowadzać normy wstrzymujące rozwój pandemii. Polska pod tym względem nie jest wyjątkiem, jednakże ze względu na wcześniejsze problemy systemowe, jej sytuacja w walce $z$ choroba od początku znajdowała się na straconej pozycji.

Jeden $z$ ekspertów zdrowia publicznego z Zakładu Monitorowania i Analiz Stanu Zdrowia Ludności Narodowego Instytutu Zdrowia Publicznego - Państwowego Zakładu Higieny, Rafał Halik, stwierdził, że kształt polskiego systemu ochrony zdrowia nie ulegnie większej zmianie pod wpływem pandemii. Uważa, że system stanie na skraju swych możliwości i wyeksploatowania pomimo niższej niż w pozostałych krajach Europy skali zachorowań. Potwierdzeniem jego przypuszczeń jest np. dopuszczenie do powstania wielu ognisk COVID-19 w szpitalach. Cytując Halika „Jest to bardzo niepokojacy sygnał dla nas wszystkich. Wbrew pozorom, zakodowana już niemal w DNA naszego systemu zdolność do improwizacji na wszystkich szczeblach może pomóc przetrwać ten czas, ale może też nas zgubić i pogrążyć w chaosie"33.

33 Pandemia koronawirusa: trudny sprawdzian $i$ katalizator zmian $w$ systemie ochrony zdrowia, Puls Medycyny [dostęp: 9 września 2020]. 
Obecna sytuacja niekorzystnie wpływa na ruch pacjentów na oddziałach szpitalnych. $Z$ powodu restrykcji epidemicznych wizyty i zabiegi sa odwlekane w czasie. W niedługiej przyszłości dużym problemem będzie rozliczenie finansowe za utrzymywanie jednostek leczniczych w gotowości oraz rozliczenie terapii pacjentów z COVID-19. Pomocna w tym zakresie może być nowa strategia postępowania Ministerstwa oraz regulacje Narodowego Funduszu Zdrowia.

Kolejnym problemem, $z$ którym będzie musiała zmierzyć się polityka zdrowotna, będzie „wypalony” personel medyczny. Duża liczba pacjentów, praca w warunkach ciagłego zagrożenia czy wielokrotne nadgodziny generuja bardzo wysoki poziom stresu, który negatywnie wpływa na kondycję fizyczną i psychiczna pracowników systemu ochrony zdrowia. Bardzo trudne będzie ponowne zmotywowanie ich do pracy, by nadrobić zaległości w leczeniu innych pacjentów. Szczególnie, że warunki przed pandemią również nie były przyjazne tak dla personelu, jak i dla pacjentów.

Pandemia znacznie przyspieszyła informatyzację polskiego systemu ochrony zdrowia. Należy przyznać, że administracja publiczna włożyła dużo pracy w przejście w tryb zdalny i telemedyczny. Potrzebne sa jednak dalsze zmiany w tej materii. Należy wzmocnić zinformatyzowany, czuły, nowoczesny nadzór epidemiologiczny, jak również inne narzędzia monitorujące sytuację zdrowotna społeczeństwa. Jest to konieczne nie tylko w Polsce, ale w całej Unii Europejskiej. W dobie COVID-19 wyraźnie widać, jak potrzebny jest paneuropejski, jednolity zinformatyzowany nadzór epidemiologiczny, który będzie zawierał system szybkiego reagowania. $\mathrm{W}$ rozwoju informatyzacji systemu ochrony zdrowia dużą rolę może pełnić uczenie maszynowe, które obecnie nie jest szeroko rozpowszechnione w tym sektorze. Obecnie wykorzystywane jest jedynie w diagnostyce. Sztuczna inteligencja może znacznie przyspieszyć prace badawczo-rozwojowe w branży farmaceutycznej ${ }^{34}$.

Warto pokreślić, że okres pandemii pokazał, że Ministerstwo Zdrowia szybko podejmowało decyzje mające wspomóc walkę $z$ choroba. Przykładem jest NFZ, który bardzo sprawnie uruchomił rozliczanie teleporad. Zaktualizował również dotychczasowe narzędzia, sprawiajacc, że odpowiadały na potrzeby personelu (np. EWUŚ pozyskał znacznik, który informuje o przebywaniu pacjenta na obowiązkowej kwarantannie). Decydenci i urzędnicy pokazali, że potrafią się sprawnie

342019 Global life sciences outlook, Deloitte, https://www2.deloitte.com/content/ dam/Deloitte/global/Documents/Life-Sciences-Health-Care/gx-lshc-ls-outlook-2019.pdf [dostęp: 9 września 2020]. 
komunikować i współpracować. Warto, by ten stan rzeczy utrzymał się również po wygaśnięciu pandemii, a metody komunikacji w systemie ochrony zdrowia były stale poprawiane i doskonalone.

Rozwój telemedycyny w Polsce jest zdecydowanie korzystnym zjawiskiem. Należy jednak wspomnieć o jej negatywnych implikacjach. Teleporady od lipca 2020 r. stały się podstawa funkcjonowania podstawowej opieki zdrowotnej. Nie dla wszystkich pacjentów taka forma kontaktu jest odpowiednia. Niezadowolenie zgłaszaja głównie pacjenci $z$ chorobami przewlekłymi, planowanymi szczepieniami czy osoby $z$ nagle pogarszajacym się stanem zdrowia. W mediach regularnie pojawiają się doniesienia o niemożności dodzwonienia się do przychodni czy braku miejsc na poradę stacjonarna. Niektórzy mówią otwarcie o zamknięciu się POZ na pacjentów, co jest niedopuszczalne. Warto, aby decydenci zwrócili baczna uwage na to zjawisko oraz rozważyli nowe wytyczne funkcjonowania POZ i ambulatoryjnej opieki specjalistycznej.

Pandemia pojawiła się nieoczekiwanie, przynosząc ze sobą kryzys gospodarczy i strach ludzi. Przezwyciężenie kryzysu zdrowotnego jest bardzo trudne w każdych warunkach. W Polsce stało się to w okresie, gdy efektywna polityka zdrowotna dopiero się kształtuje, przez co ma wiele niedociagnięć. Pandemia tylko uwypukliła problemy, takie jak niedofinansowanie systemu i niedostateczne zasoby kadry medycznej. Pomimo kryzysu i niesprzyjających warunków polska polityka zdrowotna stanęła na wysokości zadania, podejmując szybkie decyzje i rozwijajacc te obszary, które były szczególnie potrzebne w danej chwili. Pomimo tego należy ją ciagle doskonalić i optymalizować, ponieważ system ochrony zdrowia w Polsce potrzebuje jeszcze wielu usprawnień, aby w pełni zaspokoić potrzeby zdrowotne obywateli. 